\title{
Influence of genetic material and radial position on the anatomical structure and basic density of wood from Eucalyptus spp. and Corymbia citriodora
}

\author{
Influência do material genético e posição radial na estrutura anatômica e \\ densidade básica das madeiras de Eucalyptus spp. e Corymbia citriodora
}

\author{
Luiz Eduardo de Lima Melo', José Reinaldo Moreira da Silva², Alfredo Napoli³, \\ José Tarcisio Lima ${ }^{2}$, Paulo Fernando Trugilho² e Débora Fernanda Reis Nascimento ${ }^{4}$
}

\begin{abstract}
Resumo
O objetivo deste trabalho foi avaliar o efeito do material genético e da variabilidade radial na estrutura anatômica e densidade básica das madeiras de Eucalyptus sp. e Corymbia citriodora e também verificar a influência da anatomia sobre a densidade básica da madeira. Foram estudados dois híbridos naturais de Eucalyptus urophylla e a espécie Corymbia citriodora, sendo três árvores amostradas por material genético, e todos os plantios localizados no estado de Minas Gerais, Brasil. Retiraram-se nove discos (um de cada árvore) a 1,30 m do solo e a partir destes foram obtidos corpos de prova devidamente orientados da medula em direção à casca, para a determinação da anatomia e densidade básica da madeira, entre os materiais genéticos e as posições radiais. Comparativamente aos híbridos a espécie $C$. citriodora, apresentou valores superiores de espessura, fração parede e porção de parede das fibras e também densidade básica. A espécie também apresentou variação radial menos acentuada da estrutura anatômica, maior uniformidade da madeira no sentido medula-casca, características importantes para fins de madeira serrada e secagem, dentre outras aplicações que requerem mais homogeneidade da matéria prima. A fração parede e a porção de parede das fibras foram os parâmetros anatômicos que melhor explicaram a variação radial da densidade básica.
\end{abstract}

Palavras-chave: Anatomia, Propriedades físicas, Qualidade da madeira.

\begin{abstract}
The aim of this study was to evaluate the effect of genetic materials and the radial variability on anatomical structure and basic density of wood from Eucalyptus spp. and Corymbia citriodora and also to verify the influence of the anatomy on the wood basic density. Two natural hybrids of Eucalyptus urophylla and Corymbia citriodora species were studied, wherein three trees per genetic material were sampled in the state of Minas Gerais, Brazil. Nine discs (one in each tree) were removed at $1.30 \mathrm{~m}$ from the ground and from these we obtained properly oriented specimens in the pith to bark direction, for determining the anatomy and wood density among the genetic materials and radial positions. Compared to the hybrids, $C$. citriodora showed higher values for thickness, wall fraction and wall portion of the fibres and also basic density. The species also showed less pronounced radial variation of the anatomical structure, demonstrating greater uniformity of wood in the pith-bark direction, important characteristics for lumber purposes and drying, among other applications that require a more homogeneous raw material. The wall fraction and the wall portion of the fibres were the anatomical parameters that better explained the radial variation of basic density.
\end{abstract}

Keywords: Anatomy, Physical properties, Wood quality.

\section{INTRODUCTION}

In general, for forest plantations specialists seek to use genetic material that presents rapid growth associated with the production of wood of satisfactory quality for a particular use.

It must be understood that the wood differs from other raw materials especially for presenting variability of its properties in the axial and radial direction that occur due to age, genetic mate-

\footnotetext{
${ }^{1}$ Professor at Department of Technology and Natural Resources. UEPA - Universidade do Estado do Pará. Av. Hiléia, s/n Postal Code: 09 - 68503120 - Marabá, PA, Brasil. E-mail: luizeduardo.limamelo@gmail.com.

2Professor at Department of Forest Sciences. UFLA - Universidade Federal de Lavras - Campus Universitário - 37200-000 Lavras, MG - Brasil - Caixa-postal: 3037. E-mail: jreinaldo@dcf.ufla.br; jtlima@dcf.ufla.br; trugilho@dcf.ufla.br

3PhD Resarcher. La Recherche Agronomique pour le Développement, UR BioWooEB. Rue Jean-François Breton - Cirad Maison de la Technologie- 34170 - Montpellier, França. E-mail: alfredo.napoli@cirad.fr.

${ }^{4}$ Forest Engineer. UFLA - Universidade Federal de Lavras - Campus Universitário - 37200-000 - Lavras, MG - Brasil - Caixa-postal: 3037. E-mail: deborafrnascimento@gmail.com.
}

Sci. For., Piracicaba, v. 44, n. 111, p. 611-621, set. 2016 DOI: dx.doi.org/10.18671/scifor.v44n111.07 
Melo et al. - Influence of genetic material and radial position on anatomical

structure and basic density of wood from Eucalyptus sp. and Corymbia citriodora

rial, site, spacing, nutrition and environmental interactions, which influence the cambium activity responsible for the production of cells that make up the wood (ZOBEL; VAN BUIJTENEN, 1989; LARSON, 2011).

The periodic changes experienced by the cambium due to its ripening produce differences in anatomical structure and wood properties within the growth ring and also between the juvenile and adult wood.

The juvenile wood, produced in the first years of growth of the tree, differs from the mature wood, especially for presenting greater magnitude of variation in its technological properties, notably marked by sudden changes in cellular composition (ZOBEL; VAN BUIJTENEN, 1989; BAO et al., 2001; CALONEGO et al., 2005; PALERMO et al., 2015) and this almost always has a negative effect on the wood quality.

Tsuchiya and Furukawa (2009), Fan et al. (2009) and Apiolaza et al. (2013) emphasize that studies that evaluate the radial and axial variation in the trunk, besides enabling an understanding of the architecture adopted by different species to make water transport become efficient and secure, demonstrate extreme commercial importance, because from the results it is possible to predict which raw material is commercially the most indicated for a particular application.

For the use of wood as a raw material, the study of the variability of its properties mainly that observed from the pith toward the bark is of fundamental importance, mainly for splitting and drying.

According to Silva (2002) optimization in the exploitation of sawn wood will occur with the knowledge of these existing variations, as well as with their interactions with the different machining operations. This classifies the trees for specific purposes. Silva et al. (2007) add that in the splitting of the wood for board production, for example, depending on the location within the tree from where they are obtained, they can be directed to form specific components of furniture according to their particular characteristics based on the machining operations necessary for their manufacture.

The aim of this work was to evaluate the effect of the genetic material and the radial variability on anatomical structure and basic density of wood from Eucalyptus spp. and Corymbia citriodora and also to verify the influence of the anatomy on the basic wood density.

\section{MATERIAL AND METHODS}

The genetic materials analysed were two natural hybrids of Eucalyptus urophylla, MN463 and VM04, from V\&M Florestal Ltda. company, with plantations located in the central region of the state of Minas Gerais ( $19^{\circ} 16^{\prime} 54^{\prime \prime} \mathrm{S} ; 44^{\circ} 24^{\prime} 32^{\prime \prime} \mathrm{W} ; 761 \mathrm{~m}$ of altitude) and one species, Corymbia citriodora, from Cenibra S.A. company from a plantation installed in the region of the Vale do Rio Doce/MG $\left(19^{\circ} 28^{\prime} 8^{\prime} \mathrm{S} ; 42^{\circ} 32^{\prime} 12^{\prime \prime} \mathrm{W} ; 231 \mathrm{~m}\right.$ of altitude). Nine trees were sampled, three per genetic material. At collection time, the genetic materials were of age seven years and an average diameters, at $1.3 \mathrm{~m}$ from the ground, of 21.23; 15.56 and $18.34 \mathrm{~cm}$, for hybrids MN463, VM04 and for the C. citriodora species, respectively.

The trees were felled and $60 \mathrm{~mm}$ thick disks were obtained, $1.30 \mathrm{~m}$ above the soil. Samples measuring $15 \mathrm{~mm} \times 15 \mathrm{~mm} \times 60 \mathrm{~mm}$ were withdrawn from the disks, pith to bark, 2/3 of the samples being dedicated for the anatomy and the remainder for basic density determination (Figure 1 ).

Radial positions were sampled in the trees always at $1.5 \mathrm{~cm}$ from the pith, seven radial positions for the hybrid MN463, five for the VM04 hybrid and six for the C. citriodora specie.

The quantitative anatomy of the wood was performed according to the International Association of Wood Anatomists (IAWA, 1989). For the preparation of the macerated material the method of Franklin (1945) was used as for the histological slides. We performed 30 measurements for the biometrics of vessel elements (number per $\mathrm{mm}^{2}$, diameter and length) and ray (height and width) and fibres (length, width, lumen diameter). The thickness and the fibre wall fraction were calculated (Equations 1 and 2, respectively).

$$
\begin{gathered}
\text { Wall thickness }=(\text { Fibre width }- \text { Lumen diameter }) / 2 \\
\text { Wall Fraction }=\frac{2 \times \text { Wall Thickness }}{\text { Fiber } \text { Width }} \times 100
\end{gathered}
$$




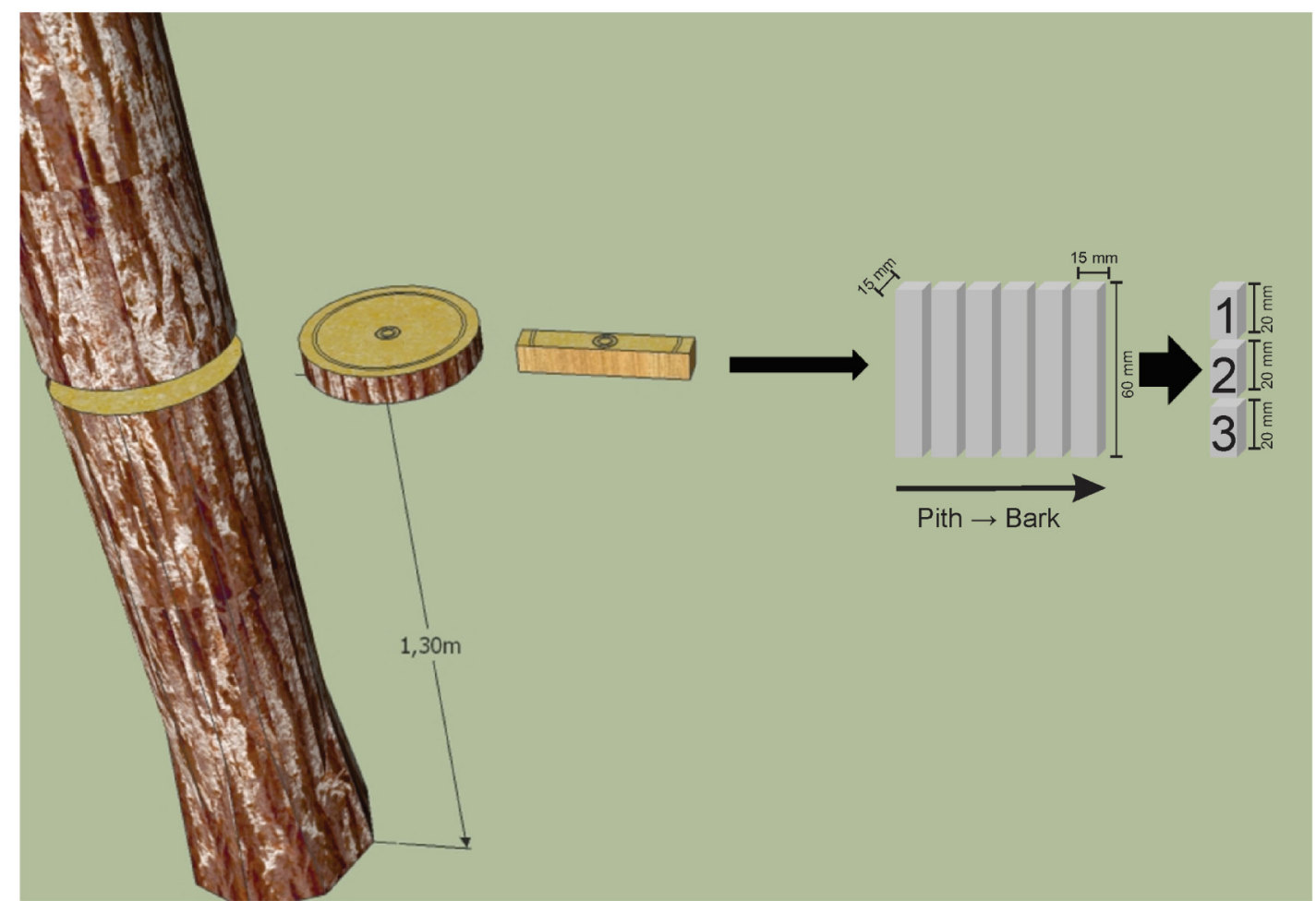

Figure 1. Scheme for preparing the wood samples in which samples 1 and 2 were destined for anatomical analyses: 1 for histological sections, 2 for maceration; and 3 for basic density.

Figura 1. Esquema de preparação das amostras. Em que destinou-se os corpos de prova 1 e 2 para as análises anatômicas, 1 . cortes histológicos, 2.maceração e o corpo de prova 3. densidade básica.

From the values of frequency and the diameter of the vessels associated with the fibre wall fraction we estimated the portion of wall fibres available per $\mathrm{mm}^{2}$. For this, Equation 3 was developed, in which the presence of parenchymatous cells was disregarded because of them being little present in the wood of the analysed species and also due to low wall thickness.

$$
F W P=\left[1-\left(F v \times \frac{\pi D v^{2}}{4}\right)\right] \times F W F
$$

In which:

FWP = Fibre wall portion, in \%;

$\mathrm{Fv}=$ number of vessels per $\mathrm{mm}^{2}$;

$\mathrm{Dv}=$ mean diameter of vessel, in $\mathrm{mm}$;

$\mathrm{FWF}=$ fibre wall fraction, in \%.

The determination of the basic density was performed according to NBR 11941 (ABNT, 2003).

In the assessment of the wood characteristics analyses of variance (ANAVA) were carried out considering a completely randomized design (CRD) arranged in a factorial design. The analysed factors were the genetic material and the radial position. For the multiple comparisons of averages, we used the Scott-Knott average test, at a 5\% significance level. From the average values obtained in radial positions sampled in the three genetic materials, Pearson correlation and linear regression were performed to verify the functional relationship between the quantitative anatomy and the wood basic density.

\section{RESULTS AND DISCUSSION}

\section{Variation of the anatomical structure and density of genetic materials}

Variance analysis revealed that, with the exception of fibre length, the effect of the genetic material analysed was significant, at a 5\% significance level by the F Test, for all the evaluated characteristics (Table 1). The effect of the sampling radial position was significant for all properties assessed, except for the lumen diameter, wall thickness, wall fraction and fibre wall portion (Table1). The interaction among genetic materials and position was significant only for the diameter and the 
length of the vessel elements and the ray length (Table 1). Significant interaction indicates that there is dependence among the factors and, thus, we chose to evaluate the effect of the radial position within the genetic materials to verify their different variation pattern.

Table 1. Summary of the analysis of variance for vessel frequency (Vf), vessel diameter (Vd), vessel element length $(\mathrm{VI})$, ray height $(\mathrm{Rh})$, ray width $(\mathrm{Rw})$, fiber length $(\mathrm{FI})$, fiber width $(\mathrm{Fw})$, fiber lumen diameter (Fd), fibre wall thickness (Ft), fibre wall fraction (FWF), fibre wall portion (FWP) and basic density.

Tabela 1. Resumo da Análise de variância para frequência dos vasos ( $\mathrm{Vf}$ ), diâmetro dos vasos (Vd), comprimento dos elementos de vaso ( $\mathrm{VI})$, altura dos raios ( $\mathrm{Rh}$ ), largura dos raios (Rw), comprimento das fibras (FI), largura da fibra (FW), diâmetro do lume das fibras (Fd), espessura da parede das fibras (Ft), fração parede das fibras (FWF), porção de parede das fibras (FWP) e densidade básica.

\begin{tabular}{|c|c|c|c|c|c|c|c|c|c|c|c|c|c|}
\hline \multirow[b]{3}{*}{$\begin{array}{l}\text { Source of } \\
\text { variation }\end{array}$} & \multirow[b]{3}{*}{ GI } & \multicolumn{12}{|c|}{ Mean Square } \\
\hline & & \multicolumn{3}{|c|}{$\begin{array}{c}\text { Vessel } \\
\text { element }\end{array}$} & \multicolumn{2}{|c|}{$\begin{array}{c}\text { Radial } \\
\text { parenchyma }\end{array}$} & \multicolumn{6}{|c|}{ Fibre } & \multirow{2}{*}{$\begin{array}{c}\text { Basic } \\
\text { density } \\
\text { g. } \mathrm{cm}^{-3}\end{array}$} \\
\hline & & $\begin{array}{c}\text { Vf por } \\
\text { mm }^{2}\end{array}$ & $\begin{array}{l}\mathrm{Vd} \\
\mu \mathrm{m}\end{array}$ & $\begin{array}{c}\mathrm{VI} \\
\mu \mathrm{m} \\
\end{array}$ & $\begin{array}{l}\text { Rh } \\
\mu \mathrm{m}\end{array}$ & $\begin{array}{l}\text { Rw } \\
\mu \mathrm{m}\end{array}$ & $\begin{array}{c}\mathrm{FI} \\
\mu \mathrm{m}\end{array}$ & $\begin{array}{l}\text { Fw } \\
\mu m\end{array}$ & $\begin{array}{l}\mathrm{Fd} \\
\mu \mathrm{m}\end{array}$ & $\begin{array}{c}\mathrm{Ft} \\
\mu \mathrm{m}\end{array}$ & $\begin{array}{c}\text { FWF } \\
\%\end{array}$ & $\begin{array}{c}\text { FWP } \\
\%\end{array}$ & \\
\hline$M$ & 2 & $145^{\star \star}$ & $2114^{* *}$ & $40600^{* \star}$ & $14920^{* *}$ & $64^{* *}$ & $514^{\mathrm{ns}}$ & $65^{\star \star}$ & $85^{\star \star}$ & $1,4^{* *}$ & $1099^{* *}$ & $1099^{* *}$ & $2114,5^{\star \star}$ \\
\hline$P$ & 6 & $43^{* *}$ & $751^{* *}$ & $17782^{* *}$ & $1020^{* *}$ & $2^{\mathrm{ns}}$ & $10900^{* *}$ & $12^{* *}$ & $6^{\text {ns }}$ & $0,6^{\text {ns }}$ & $58^{\text {ns }}$ & $58^{\text {ns }}$ & $751,5^{\star *}$ \\
\hline$M \times P$ & 11 & $3^{\text {ns }}$ & $223^{* *}$ & $5326^{* *}$ & $775^{\star *}$ & $2^{\mathrm{ns}}$ & 16124 ns & $8^{\text {ns }}$ & $5^{\text {ns }}$ & $0,07^{\mathrm{ns}}$ & $2^{\text {ns }}$ & $2^{\text {ns }}$ & $223,1^{\text {ns }}$ \\
\hline Error & 34 & 98,3 & 62,8 & 1891 & 358,9 & 3,3 & 8678 & 1,7 & 3,7 & 0,1 & 52,4 & 52,4 & $62,8^{\mathrm{ns}}$ \\
\hline CVe (\%) & - & 15 & 7 & 12 & 8 & 12 & 10 & 8 & 20 & 10 & 15 & 13 & 7,7 \\
\hline
\end{tabular}

$\mathrm{GI}=$ degrees of freedom; ** significant at the $5 \%$ significance by $\mathrm{F}$ test; $\mathrm{ns}=$ not significant at the $5 \%$ significance by $\mathrm{F}$ test; $\mathrm{M}=$ genetic material; $\mathrm{P}=$ radial position; $\mathrm{CVe}=$ experimental coefficient of variation.

Table 2 shows the descriptive statistical data and also those of multiple comparisons of averages performed for the characteristics assessed among the genetic material. The hybrid MN463 showed, on average, higher vessel per $\mathrm{mm}^{2}$ frequency, ray length and width and fibre lumen diameter values, while the hybrid VM04 obtained the highest values for vessel diameter, vessel element length and fibre length and width. However, the species C. citriodora had the highest values of basic density, thickness, wall fraction and fibre wall portion.

The average values found for the anatomical parameters of the hybrids studied are close to the values available in the literature for the wood of E. urophylla (OLIVEIRA, 1997; EVANGELISTA et al., 2010; BRISOLA; DEMARCO, 2011). However, the fibre length values were slightly lower than those obtained by Trugilho et al. (2007) for E. urophylla clones at 5.8 years of age. As for the results obtained for the basic density of hybrids we observed that they are close to the values determined by Couto et al. (2013) and Trugilho et al. (2015). For the species C. citriodora, the mean values observed for vessel frequency are below those obtained by Benjamin (2006) for juvenile wood of the same species, however the vessel diameter values are in agreement with the results of this present research; the results obtained for the length of the vessel elements and the parameters related to the fibres are similar to those obtained by Palma et al. (2010), and Lemos et al. (2012). The average value of basic density for the species was higher than that of the hybrids, and this is in accordance with the studies of Lemos et al. (2012) and Lourenço et al. (2013).

Differences in the wood properties among genetic materials, even those from cloning, are remarkable within species of Eucalyptus, and the magnitude of these differences vary substantially. In this study it was observed, in general, that the species $C$. citriodora at seven years of age presented the lowest vessel frequency, width and fibre lumen diameter and at the same time presented higher values of thickness, wall fraction and fibre wall portion and also basic density. These are characteristics commonly related to higher mechanical resistance of wood for general use and are also strong prerequisites for the raw material use as an energy source (UETIMANE; ALI, 2011; SOARES et al. 2014).

We observed in the radial variation that the vessel diameter and ray height in hybrid VM04 presented an increasing variation pattern in the pith-bark direction; the hybrid MN463 presented increasing values up to $7 \mathrm{~cm}$ for the vessel diameter and up to $5.5 \mathrm{~cm}$ for the ray height and from this distance from the pith a reduction of the values for both anatomical parameters was observed; however C. citriodora showed no significant differences among the radial positions sampled (Figure $2 \mathrm{a}, \mathrm{b})$. For the vessel element length, both hybrids presented an increasing pattern of variation in the pith-bark direction, while C. citriodora showed no significant differences among the radial positions (Figure 2c). 
Table 2. Descriptive statistics and mean comparison among genetic materials for vessel frequency (Vf), vessel diameter $(\mathrm{Vd})$, vessel element length $(\mathrm{VI})$, ray height $(\mathrm{Rh})$, ray width $(\mathrm{Rw})$, fibre length $(\mathrm{FI})$, fibre width $(\mathrm{Fw})$, fibre lumen diameter (Fd), fibre wall thickness (Ft), fibre wall fraction (FWF), fibre wall portion (FWP) and basic density $(\mathrm{Bd})$.

Tabela 2. Estatística descritiva e comparação das médias entre os materiais genéticos, para frequência dos vasos (Vf), diâmetro dos vasos (Vd), comprimento dos elementos de vaso (VI), altura dos raios (Rh), largura dos raios $(\mathrm{Rw})$, comprimento das fibras $(\mathrm{FI})$, largura da fibra ( $\mathrm{Fw})$, diâmetro do lume das fibras (Fd), espessura da parede das fibras (Ft), fração parede das fibras (FWF), porção de parede das fibras (FWP) e densidade básica $(\mathrm{Bd})$.

\begin{tabular}{|c|c|c|c|}
\hline \multirow{2}{*}{ Evaluated properties } & \multicolumn{3}{|c|}{ Genetic material } \\
\hline & MN463 & VM04 & C. citriodora \\
\hline $\mathrm{Vf}\left(\right.$ por $\left.\mathrm{mm}^{2}\right)$ & $\begin{array}{c}13,5^{\mathrm{a}} \\
(5-27)[31]\end{array}$ & $\begin{array}{c}11,1^{\mathrm{b}} \\
(1-23)[33]\end{array}$ & $\begin{array}{c}7,9^{c} \\
(2-18)[34]\end{array}$ \\
\hline $\mathrm{Vd}(\mu \mathrm{m})$ & $\begin{array}{c}92,9^{c} \\
(36-160)[20]\end{array}$ & $\begin{array}{c}115,5^{a} \\
(55-168)[18]\end{array}$ & $\begin{array}{c}102,4^{\mathrm{b}} \\
(44-154)[19]\end{array}$ \\
\hline $\mathrm{VI}(\mu \mathrm{m})$ & $\begin{array}{c}346,9^{\mathrm{b}} \\
(123-690)[29]\end{array}$ & $\begin{array}{c}387,6^{\mathrm{a}} \\
(128-805)[33]\end{array}$ & $\begin{array}{c}289,2^{c} \\
(105-606)[29]\end{array}$ \\
\hline $\mathrm{Rh}(\mu \mathrm{m})$ & $\begin{array}{c}239,6^{\mathrm{a}} \\
(105-476)[20]\end{array}$ & $\begin{array}{c}213,7^{\mathrm{b}} \\
(91-394)[24] \\
\end{array}$ & $\begin{array}{c}182,4^{\mathrm{c}} \\
(82-367)[25]\end{array}$ \\
\hline $\mathrm{Rw}(\mu \mathrm{m})$ & $\begin{array}{c}15,8^{a} \\
(5-27)[20]\end{array}$ & $\begin{array}{c}12,2^{\mathrm{b}} \\
(5-24)[26]\end{array}$ & $\begin{array}{c}15,4^{a} \\
(5-29)[29]\end{array}$ \\
\hline $\mathrm{FI}(\mu \mathrm{m})$ & $\begin{array}{c}875,5^{a} \\
(484-1321)[18]\end{array}$ & $\begin{array}{c}886,2^{a} \\
(415-1632)[25]\end{array}$ & $\begin{array}{c}878,8^{a} \\
(411-1492)[21] \\
\end{array}$ \\
\hline $\mathrm{Fw}(\mu \mathrm{m})$ & $\begin{array}{c}18,1^{\text {a }} \\
(9-34)[19]\end{array}$ & $\begin{array}{c}16,2^{\mathrm{b}} \\
(7-27)[20]\end{array}$ & $\begin{array}{c}14,4^{c} \\
(8-24)[16]\end{array}$ \\
\hline $\mathrm{Fd}(\mu \mathrm{m})$ & $\begin{array}{c}10,6^{a} \\
(3-22)[31] \\
\end{array}$ & $\begin{array}{c}9,3^{\mathrm{b}} \\
(3-18)[29]\end{array}$ & $\begin{array}{c}6,4^{c} \\
(2-18)[37] \\
\end{array}$ \\
\hline $\mathrm{Ft}(\mu \mathrm{m})$ & $\begin{array}{c}3,8^{\mathrm{a}} \\
(1-8)[21]\end{array}$ & $\begin{array}{c}3,4^{\mathrm{b}} \\
(2-7)[23]\end{array}$ & $\begin{array}{c}4,0^{\mathrm{a}} \\
(2-7)[21]\end{array}$ \\
\hline FWF(\%) & $\begin{array}{c}42,6^{\mathrm{b}} \\
(19-77)[20]\end{array}$ & $\begin{array}{c}43,0^{\mathrm{b}} \\
(20-78)[21]\end{array}$ & $\begin{array}{c}56,5^{a} \\
(21-85)[21] \\
\end{array}$ \\
\hline FWP (\%) & $\begin{array}{c}38,7^{\mathrm{b}} \\
(16-74)[23]\end{array}$ & $\begin{array}{c}38,2^{\mathrm{b}} \\
(18-72)[22]\end{array}$ & $\begin{array}{c}53,2^{a} \\
(22-19)[21]\end{array}$ \\
\hline $\mathrm{Bd}\left(\mathrm{g} / \mathrm{cm}^{-3}\right)$ & $\begin{array}{c}0,47^{b} \\
(0,38-0,57)[10]\end{array}$ & $\begin{array}{c}0,48^{\mathrm{b}} \\
(0,43-0,54)[8]\end{array}$ & $\begin{array}{c}0,56^{\mathrm{a}} \\
(0,42-0,72)[16]\end{array}$ \\
\hline
\end{tabular}

The values in parentheses refer to the minimum and the maximum; and value in brackets refers to the coefficient of variation (\%). Means followed by the same letter in the columns do not differ by the Scott-Knott test at $5 \%$ significance.

The basic density and the length and the width of the fibres presented a pattern of increasing variation in the pith-bark direction. We also observed more uniform behavior in C. citriodora (Figure 4). When analysing fibre length radial variation profile of the genetic material, it can be concluded that the wood analysed still comprises the juvenile region of the trees, since stabilization of the average values was not observed from the pith to the entire extension of the ray and the values obtained demonstrated a pattern of increasing variation until near the bark, despite the less marked variation observed in C. citriodora (Figure 4).

The frequency of vessels per $\mathrm{mm}^{2}$ exhibited a significant reduction in the pith-bark direction for all genetic materials analysed; but we observed less accentuated radial variation values in C. citriodora (Figure 3).

For the other anatomical parameters evaluated a significant effect of the radial position and interaction with the genetic material was not observed.

The frequency reduction accompanied by the vessel diameter increase in the pith-bark direction observed mainly in hybrid VM04 was also reported by Oliveira (1997), Sousa Jr. (2004) and Evangelista et al. (2010) studying E. urophylla wood. The radial uniformity of the vessel diameter compared to the significant frequency decrease observed in C. citriodora was also recorded by Benjamin (2006) for the same species. The main explanation for the increase in the vessel diameter being associated to lower frequency in the radial direction is found in the polar flow of auxin produced in young leaves. The vessel elements produced closer to the top, which later will be restricted to the region close to the pith, are influenced by the higher concentration of auxin that induces a rapid cell differentiation, while low concentration levels of this hormone in the most distant regions stimulates slow differentiation, which allows more time for cell development and secondary wall de- 
Melo et al. - Influence of genetic material and radial position on anatomical

structure and basic density of wood from Eucalyptus sp. and Corymbia citriodora

position; consequently resulting in larger diameter and lower frequency of vessel elements (ALONI; ZIMMERMANN, 1983; ALONI, 2007).
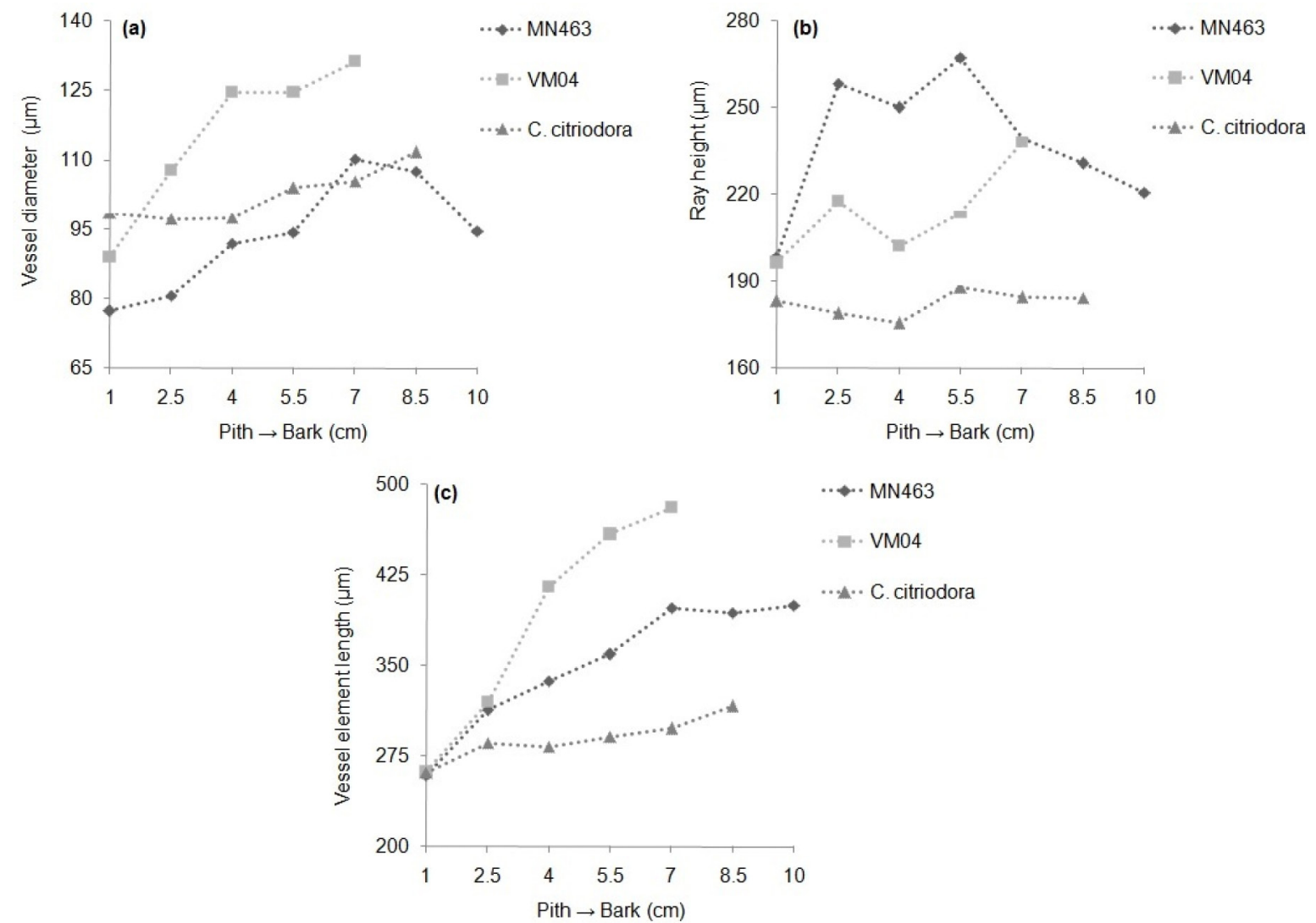

Figure 2. Profile of radial variation among genetic materials: a. vessel diameter; b. ray height; c. vessel element length.

Figura 2. Perfil de variação radial entre os materiais genéticos. a. diâmetro dos vasos; b. comprimento dos raios; c. comprimento dos elementos de vaso.

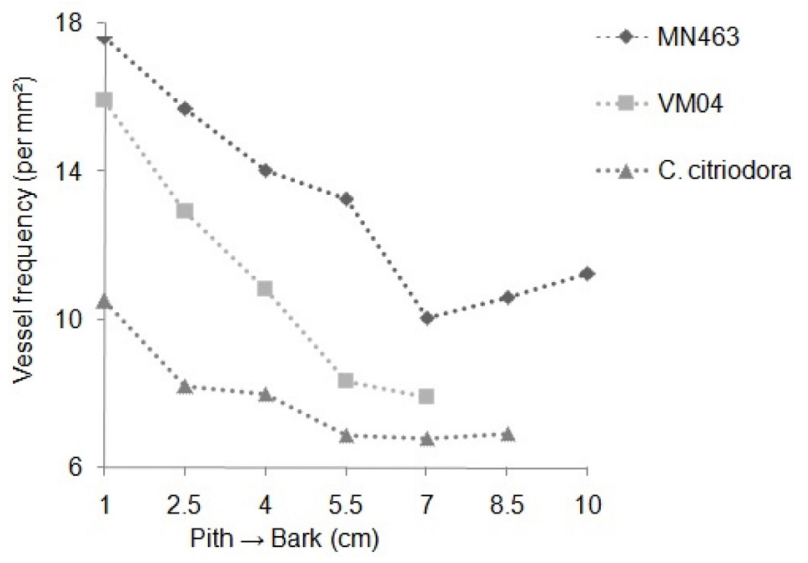

Figure 3. Radial variation for vessel frequency per $\mathrm{mm}^{2}$.

Figura 3. Variação radial para a frequência de vasos por $\mathrm{mm}^{2}$.

The progressive increase of fibre length in the pith-bark direction can be associated to mainly quantitative anatomical differences deriving from the cambium maturation process and consequently of the woody tissue (LARSON, 2011). These differences during tree development will reflect in the formation of wood with different properties, which differentiate the juvenile and adult wood. In species of rapid growth, such as some members in the genus Eucalyptus, such differences may be more evident due to the more accelerated growth rate that marks the juvenile wood formation period (FANG; YANG, 2003; LEAL et al., 2003; RAMÍREZ et al., 2009; PALERMO et al., 2015 ). 

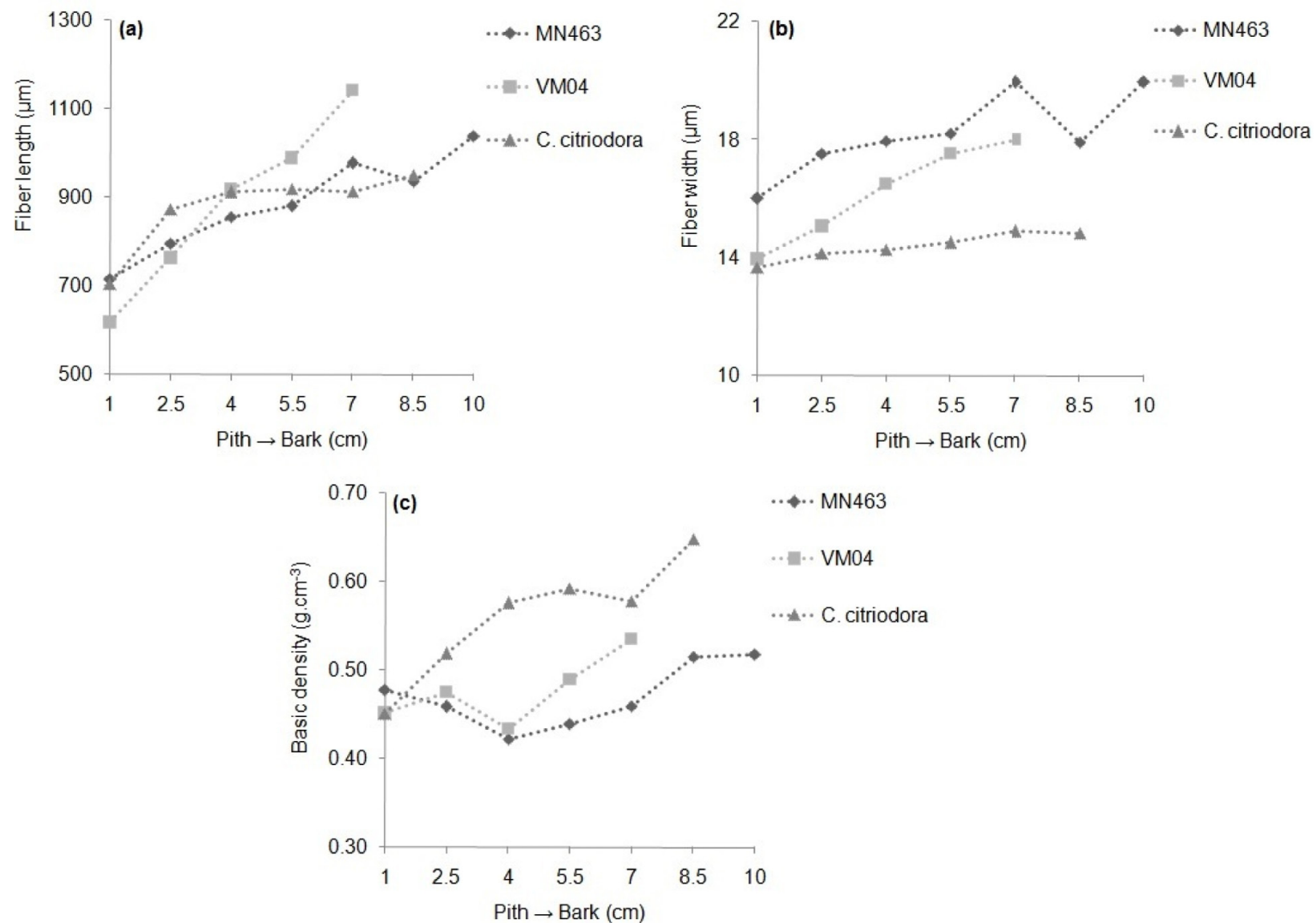

Figure 4. Radial variation for: a. fibre length; b. fibre width; c. basic density.

Figura 4. Variação radial para: a. comprimento das fibras; b. largura das fibras; c. densidade básica.

\section{Correlations between the anatomical structure and basic density}

Significant correlations were found between the basic densities with some anatomical parameters evaluated. A strong negative correlation was observed with vessel frequency and a moderate negative correlation with the ray height and fibre lumen diameter (Table 3). We observed a moderate positive correlation with the fibre wall thickness, and strong positive correlations with the wall fraction and fibre wall portion (Table 3).

Table 3. Correlation coefficients between the anatomical parameters and the wood basic density. Tabela 3. Coeficientes de correlação entre os parâmetros anatômicos e a densidade básica da madeira.

\begin{tabular}{llcc}
\hline \multirow{2}{*}{ Cell } & Anatomical parameters & \multicolumn{2}{c}{ Basic density } \\
\cline { 3 - 4 } Vessel element & Vessel frequency $\left(\right.$ per $\left.\mathrm{mm}^{2}\right)$ & $-0,72$ & Significance \\
& Diameter $(\mu \mathrm{m})$ & 0,23 & $\mathrm{~ns}$ \\
& Lenght $(\mu \mathrm{m})$ & $-0,11$ & $\mathrm{~ns}$ \\
\hline \multirow{2}{*}{ Radial parenchyma } & Height $(\mu \mathrm{m})$ & $-0,54$ & $\mathrm{~ns}$ \\
& Width $(\mu \mathrm{m})$ & 0,09 & $\mathrm{~ns}$ \\
& Lenght $(\mu \mathrm{m})$ & 0,42 & $*$ \\
\multirow{3}{*}{ Fibre } & Lumen diameter $(\mu \mathrm{m})$ & $-0,58$ & $\mathrm{~ns}$ \\
& Wall thickness $(\mu \mathrm{m})$ & 0,67 & $*$ \\
& Width $(\mu \mathrm{m})$ & $-0,33$ & $*$ \\
\hline
\end{tabular}

$r=$ correlation coefficient; ${ }^{*}=$ statistically significant at the $5 \%$ level of significance; $n s=$ not significant.

The simple linear model was the best to describe the influence of the anatomical parameters on the basic density.

There was a basic density reduction tendency as vessel frequency, ray height and fibre lumen diameter increased. Among these anatomical parameters the vessel frequency per $\mathrm{mm}^{2}$ was the characteristic that presented the best functional relationship to basic density (Figure 5). 
Melo et al. - Influence of genetic material and radial position on anatomical

structure and basic density of wood from Eucalyptus sp. and Corymbia citriodora
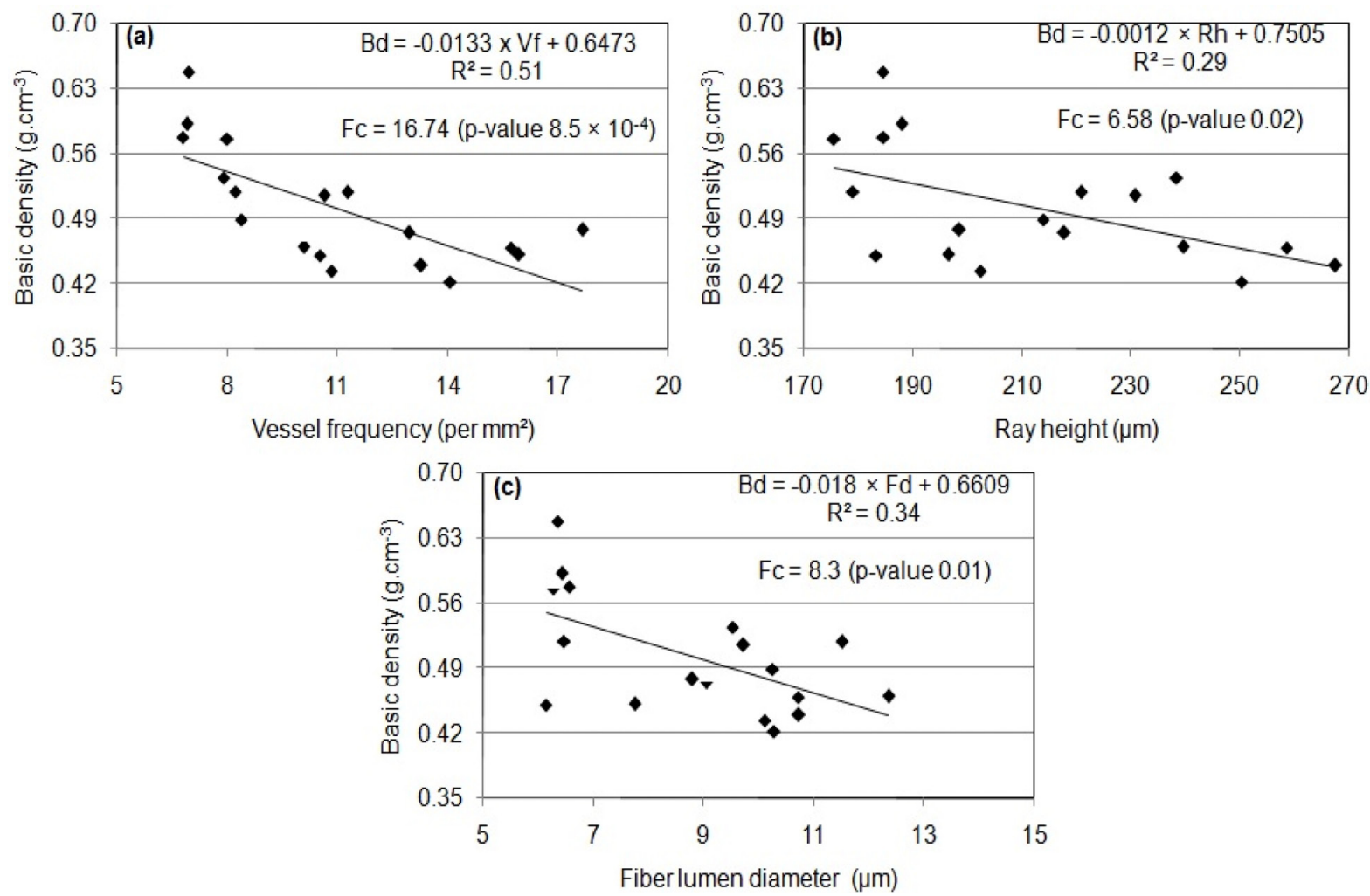

Figure 5. Functional relationship between vessel frequency (a), ray height (b), fiber lumen diameter (c) with basic density.

Figura 5. Relação funcional entre a frequência dos vasos (a), altura dos raios (b) e diâmetro do lume das fibras (c) com a densidade básica.

There was a tendency towards an increase in the basic density with increased wall thickness, wall fraction and fibre wall portion (Figure 6). The wall fraction and fibre wall portion, in isolation, were the characteristics that presented the best functional relationship to basic density (Figure $6 \mathrm{~b}$ and c).


Figure 6. Functional relationship between the fibre wall thickness (a), fibre wall fraction (b), fibre wall portion (c) with the basic density.

Figura 6. Relação funcional entre a espessura da parede das fibras (a), fração parede das fibras (b), e porção de parede das fibras (c) com a densidade básica. 
The regression analysis showed that the anatomical parameters, wall fraction and fibre wall portion were more effective to explain the radial behavior of the basic density in the genetic materials evaluated. This result shows that the wood basic density value is dependent on the percentage of cell wall effectively available per $\mathrm{mm}^{2}$ at the different radial points sampled, and that, in general, when there is an increase of this percentage, there is also an increase of the average wood density values.

According to Panshin and Zeeuw (1964), wall and the cell size are the factors that most influence the wood density variation. The thickness of the fibre cell walls and its fractionated volume can positively influence the wood density (ROQUE; TOMAZELLO-FILHO, 2007; SALMÉN; BURGERT, 2009; UETIMANE; ALI, 2011; KIAEI; BAKHSHI, 2014). According to Poorter et al. (2010) in most of the hardwood species the fibres comprise the largest part of the woody tissue (26 to $74 \%$ of cross-section area). This fact leads to the understanding of the influence of this anatomical parameter on the wood density.

\section{CONCLUSIONS}

Compared to the E. urophylla hybrids, C. citriodora presented higher values of thickness, wall fraction and wall portion of the fibres and also basic density. This species also showed greater uniformity for the evaluated properties in the pith-bark direction, which are important characteristics for purposes of sawn wood and drying, among other applications that require greater raw material homogeneity.

The wood analysed at 7 years of age still comprised the juvenile region of the trees.

The wall fraction and the wall portion of the fibres were the anatomical parameters that best explained the radial variation of the basic density in the genetic materials evaluated.

\section{ACKNOWLEDGMENTS}

The authors express their special thanks to Vallourec Florestal Ltda, Coordenação de Aperfeiçoamento de Pessoal de Nível Superior (CAPES), and Fundação de Amparo à Pesquisa do Estado de Minas Gerais (FAPEMIG) for supporting the experimental work.

\section{REFERENCES}

ALONI, R. Phytohormonal mechanisms that control wood quality formation in young and mature trees. In: THE COMPROMISED WOOD WORKSHOP. Proceedings...Christchurch: University of Canterbury, 2007.

ALONI, R.; ZIMMERMANN, M. H. The control of vessel size and density along the plant axis - A new hypothesis. Differentiation, Saint Paul, v. 24, n. 1-3, p. 203-208, 1983.

APIOLAZA, L.; CHAUHAN, S.; HAYES, M.; NAKADA, R.; SHARMA, M.; WALKER, J. Selection and breeding for wood quality: a new approach. New Zealand Journal of Forestry, Rotorua, v. 58, n. 33, p. 32-37, 2013.

ABNT - ASSOCIAÇÃO BRASILEIRA DE NORMAS TÉCNICAS. NBR 11941: Madeira - determinação da densidade básica. Rio de Janeiro, 2003. 6 p.

BAO, F. C.; JIANG, Z. H.; JIANG, X. M.; LU, X. X.; LUO, X. Q.; ZHANG, S. Y. Differences in wood properties between juvenile wood and mature wood in 10 species grown in China. Wood Science and Technology, New York, v. 35, n. 4, p. 363-375, 2001.

BENJAMIN, C. A. Estudo da estrutura anatômica e das propriedades físico-mecânicas da madeira de Corymbiacitriodora. 2006. 158 p. Tese (Doutorado) - Universidade Estadual Paulista "Julio de Mesquita Filho", São Paulo, 2006.

BRISOLA, S. H.; DEMARCO, D. Análise anatômica do caule de Eucalyptus grandis, E. urophylla e E. grandis $\mathrm{x}$ urophylla: desenvolvimento da madeira e sua importância para a indústria. Scientia Forestalis, Piracicaba, v. 39, n. 91, p. 317-330, 2011. 
Melo et al. - Influence of genetic material and radial position on anatomical

structure and basic density of wood from Eucalyptus sp. and Corymbia citriodora

CALONEGO, F. W.; SEVERO, E. T. D.; ASSI, P. P. Mensuração do comprimento das fibras para a determinação da madeira juvenil em Eucalyptus citriodora. Scientia Forestalis, Piracicaba, n. 68, p. 113-121, 2005.

COUTO, A. M.; TRUGILHO, P. F; NEVES, T. A.; PROTÁSIO, T. P.; SÁ, V. A. Modeling of basic density of wood from Eucalyptus grandis and Eucalyptus urophylla using nondestructive methods. Cerne, Lavras, v. 19, n. 1, p. 27-34, 2013.

EVANGELISTA, W. V.; SILVA, J. C.; VALLE, M. L. A.; XAVIER, B. A. Caracterização anatômica quantitativa da madeira de clones de Eucalyptus camaldulensis Dehnh. e Eucalyptus urophylla S.T. Blake. Scientia Forestalis, Piracicaba, v. 38, n. 86, p. 273-284, 2010.

FAN, Z. X.; CAO, K. F.; BECKER, P. Axial and radial variations in xylem anatomy of angiosperm and conifer trees in yunnan, China. IAWA Journal, Utrecht, v. 30, n. 1, p. 1-13, 2009.

FANG, S. Z.; YANG, W. Z. Interclonal and within-tree variation in wood properties of poplar clones. Journal of Forest Research, Tóquio, v. 14, n. 4, p. 263-268, 2003.

FRANKLIN, G. L. Preparation of thin sections of synthetic resins and wood-resin composites, and a new macerating method for wood. Nature, London, v. 155, n. 3924, p. 151, 1945.

IAWA - INTERNATIONAL ASSOCIATION OF WOOD ANATOMISTS. List of microscopic features for hardwood identification - with an appendix on non-anatomical information. IAWA Bulletin, Leiden, v. 10, n. 3, p. 219-332, 1989.

KIAEI, M.; BAKHSHI, R. Radial variations of wood different properties in Diospyros lotus. Forest Systems, Madrid, v. 23, n. 1, p. 171-177, 2014.

LARSON, P. R. The vascular cambium development and structure. Heildelberg: Springer Verlag. 2011.725 p.

LEAL, S.; PEREIRA, H.; GRABNER, M.; WIMMER, R. Clonal and site variation of vessels in 7-year-old Eucalyptus globulus. IAWA Journal, Utrecht, v. 24, n. 2, p. 185-195, 2003.

LEMOS, A. L. F.; GARCIA, R. A.; LOPES, J. O.; CARVALHO, A. M.; LATORRACA, J. V. F. Madeira de Corymbia citriodora (Hook.) K.D. Hill \& L.A.S. Johnson sob Aspectos Físicos e Anatômicos como Fatores Qualitativos. Floresta e Ambiente, Seropédica, v. 19, n. 1, p. 1-8, 2012.

LOURENÇO, T.; GATTO, D.; MATTOS, B.; DELUCIS, R. Propriedades físicas da madeira de Corymbiacitriodora no sentido radial. Scientia Forestalis, Piracicaba, v. 41, n. 99, p. 369-375, 2013.

OLIVEIRA, J. T. S. Caracterização da madeira de eucalipto para a construção civil. 1997. 2 v. 429 p. Tese (Doutorado em Engenharia) - Universidade de São Paulo, São Paulo, 1997.

PALERMO, G. P. M.; LATORRACA, J. V. F.; CARVALHO, A. M.; COLONEGO, F. W.; SEVERO, E. T. D. Anatomical properties of Eucalyptus grandis wood and transition age between the juvenile and mature woods. European Journal of Wood and Wood Products, Berlin, v. 73, n. 4, p. 423 -562, 2015.

PALMA, H. F. L.; LEONELlO, E. C.; BALlARIN, A. W. Demarcação da madeira juvenil e adulta de Corymbiacitriodora. Cerne, Lavras, v. 16, Suplemento, p. 141-148, 2010.

PANSHIN, A. J.; ZEEUW, C. Textbook of wood technology: structure, identification, properties and uses of the commercial woods of the United States and Canada. 3.ed. New York: McGraw-Hill, 1964. 643 p. 
POORTER, L. ; MCDONALD, I.; ALARCÓN, A.; FICHTLER, E.; LICONA, J. C.; PEÑA-CARLOS, M.; STERCK, F; VILLEGAS, Z.; SASS-KLAASSEN, U. The importance of wood traits and hydraulic conductance for the performance and life history strategies of 42 rainforest tree species. New Phytologist, Hoboken, v. 185, n. 2, p. 481-492, 2010.

RAMíREZ, M.; RODRÍGUEZ, J.; PEREDO, M.; VALENZUELA, S.; MENDONÇA, R. Wood anatomy and biometric parameters variation of Eucalyptus globulus clones. Wood Science and Technology, New York, v. 43, n. 1-2, p. 131-141, 2009.

ROQUE, R. M.; TOMAZELO, M. Relationships between anatomical features and intra-ring wood density profiles in Gmelinaarborea applying X-ray densitometry. Cerne, Lavras, v. 13, n. 4, p. 384-392, 2007.

SALMÉN, L.; BURGERT, I. Cell wall features with regard to mechanical performance. A review COST Action E35 2004-2008: Wood machining - micromechanics and fracture. Holzforschung, Berlin, v. 63, n. 2, p. 121$129,2009$.

SILVA, J. R. M. Relações da usinabilidade e aderência do verniz com as propriedades fundamentais do Eucalyptus grandis Hill ex. Maiden. 2002. 179 p. Tese (Doutorado em Engenharia Florestal) - Universidade Federal do Paraná, Curitiba, 2002.

SILVA, J. R. M.; LIMA, J. T.; TRUGILHO, P. F. Wood workability of Eucalyptus grandis in different region from pith to bark. Cerne, Lavras, v. 13, n. 1, p. 25-31, 2007.

SOARES, V. C.; BIACHI, M. L.; TRUGILHO, P. F.; PEREIRA, A. J.; HOFLER, J. Correlations between the properties of Eucalyptus hybrids wood and charcoal. Revista Arvore, Viçosa, v. 38, n. 3, p. 543-549, 2014.

SOUSA JR., W. P. Propriedades físicas, mecânicas e anatômicas das madeiras de Eucalyptus cloeziana e de Eucalyptus urophylla oriundas dos municípios de Turmalina e de Paraopeba (MG). 2004. 64 p. Dissertação (Mestrado em Ciência Florestal) - Universidade Federal de Viçosa, Viçosa, 2004.

TRUGILHO, P. F.; BIANCHI, M. L.; ROSADO, S. C. S.; LIMA, J. T. Qualidade da madeira de clones de espécies e híbridos naturais de Eucalyptus. Scientia Forestalis, Piracicaba, n. 73, p. 55-62, 2007.

TRUGILHO, P. F.; GOULART, S. L; ASSIS, C. O.; COUTO, F. B. S.; ALVES, I. C. N.; PROTÁSIO, T. P.; NAPOLI, A. Características de crescimento, composição química, física e estimativa de massa seca de madeira em clones e espécies de Eucalyptus jovens. Ciência Rural, Santa Maria, v. 45, n. 4, p. 661-666, 2015.

TSUCHIYA, R.; FURUKAWA. I. Radial variation in the size of axial elements in relation to stem increment in Quercusserrata. IAWA Journal, Utrecht, v. 30, n. 1, p. 15-26, 2009.

UETIMANE, E.; ALI, A. C. Relationship between mechanical properties and selected anatomical features of ntholo (Pseudolachnostylis maprounaefolia).Journal of Tropical Forest Science, Kuala Lumpur, v. 23, n. 2, p. $166-176,2011$.

ZOBEL, B. J.; VAN BUIJTENEN, J. P. Wood variation: its causes and control. Berlin: Springer-Verlag, 1989. 361 p.

Recebido em 20/03/2015

Aceito para publicação em 29/01/2016

Sci. For., Piracicaba, v. 44, n. 111, p. 611-621, set. 2016

DOI: dx.doi.org/10.18671/scifor.v44n111.07 
